\title{
Lumateperone tosylate, A Selective and Concurrent Modulator of Serotonin, Dopamine, and Glutamate, in the Treatment of Schizophrenia
}

Kunal Maini, MD', Janice W. Hollier, MD'1, Haley Gould, BS², Victoria Bollich, BS², John LaForge, BS², Elyse M. Cornett, $\mathrm{PhD}^{3}$, Amber N. Edinoff, MD ${ }^{1}{ }^{\circ}{ }^{a}$, Adam M. Kaye, PharmD ${ }^{4}$, Alan D. Kaye, MD, PhD ${ }^{3}$

1 Department of Psychiatry and Behavioral Medicine, Louisiana State University Shreveport, LA, ${ }^{2}$ Louisiana State University Shreveport School of Medicine, Shreveport, LA, ${ }^{3}$ Department of Anesthesiology, Louisiana State University Shreveport, LA, ${ }^{4}$ Department of Pharmacy Practice, Thomas J. Long School of Pharmacy and Health Sciences, University of the Pacific, Stockton, CA

Keywords: caplyta, lumateperone tosylate, schizophrenia treatment, schizophrenia

https://doi.org/10.52965/001c.24932

Health Psychology Research

Vol. 9, Issue 1, 2021

\section{Purpose of Review}

This is a comprehensive review of the literature regarding the use of Lumateperone tosylate for schizophrenia. This review presents the background, evidence, and indications for the use of lumateperone tosylate in the treatment of schizophrenia.

\section{Recent Findings}

Schizophrenia is a chronic mental health disorder that affects approximately 3.3 million people in the United States. Its symptoms, which must be present more than six months, are comprised of disorganized behavior and speech, a diminished capacity to comprehend reality, hearing voices unheard by others, seeing things unseen by others, delusions, decreased social commitment, and decreased motivation. The majority of these symptoms can be managed with antipsychotic medication.

Lumateperone is a selective and concurrent modulator of serotonin, dopamine, and glutamate, which all mediate or modulate serious mental illness.

\section{Summary}

Schizophrenia is a complex, severe mental illness that affects how the brain processes information. There are many medications used to treat schizophrenia. One antipsychotic agent, lumateperone tosylate, is a newer agent that the FDA recently approved. The most common adverse effects are shown to be mild such as somnolence, constipation, sedation, and fatigue, with the $42 \mathrm{mg}$ recommended dose. Lumateperone tosylate is an FDA-approved drug that can be given only at the $42 \mathrm{mg}$ dose once daily with no titration requirements.

\section{INTRODUCTION}

Schizophrenia is a complex, severe mental illness that affects how the brain processes information. The symptoms are broad but can be separated into three categories: positive, negative, or cognitive symptoms. ${ }^{1}$ Positive symptoms are behaviors that are not present in a healthy individual.
These can include hallucinations, delusions, confused thoughts, and unusual body movements. ${ }^{2}$ Negative symptoms can be defined as the absence of certain behaviors, such as apathy, lack of emotion, or motivation and reduced facial expressions. ${ }^{2}$ Lastly, cognitive symptoms can consist of memory impairment, attention problems, and learning difficulties. ${ }^{3}$ Patients usually present with positive symp-

\footnotetext{
Corresponding author:

Amber Edinoff, MD

Louisiana State University Shreveport

Department of Psychiatry and Behavioral Medicine

1501 Kings Hwy

Shreveport, LA- 71103

Phone: (318)675-8969

Amber.edinoff@lsuhs.edu
} 
toms to a clinician, but the negative and cognitive symptoms together can create a long-term burden on the patient. ${ }^{4}$ The onset of cognitive and social impairments can be present from the time of early adolescence. ${ }^{5}$ However, it frequently isn't until the onset of psychosis that patients are referred to a clinician. This onset usually occurs in early adulthood and differs between sexes. The onset of this disorder for males is typically in their early twenties, while the onset for females is slightly later in their early thirties. ${ }^{6}$ Schizophrenia affects approximately $1 \%$ of the population worldwide. ${ }^{7}$ Patients with this disorder typically have a life expectancy that is 20 years less than the general population. ${ }^{8}$ These patients also face difficulties in multiple aspects of their everyday life, such as social and occupational impairments that can persist long-term. This can manifest as having trouble maintaining employment and relationships. ${ }^{9}$ This may be due to the negative symptoms and cognitive deficits that patients are facing. ${ }^{10}$ While there is an importance in treating positive symptoms, addressing negative and cognitive symptoms may help to improve these patients' quality of life.

Antipsychotics are the cornerstone of treatment for schizophrenia. There are two main classes of antipsychotics. First-generation antipsychotics, also known as conventional antipsychotics, were first used to treat schizophrenia. These medications treat largely positive symptoms of schizophrenia. ${ }^{11}$ Second-generation antipsychotics, or atypical antipsychotics, also primarily treat positive symptoms. Both of these classes act as dopamine type 2 receptor $\left(D_{2} R\right)$ antagonists. ${ }^{12}$ However, atypical antipsychotics also act to block serotonin receptors such as $5-\mathrm{HT}_{2 \mathrm{~A}} \cdot{ }^{11}$ There seems to be no significant difference in the efficacy of these two classes. ${ }^{13}$ These antipsychotic medications also show limited efficacy for negative symptoms and cognitive deficits. ${ }^{14}$ the development of drugs that treat positive symptoms was a significant step towards improving patients' quality of life. Still, it did not completely solve the problems that patients face.

As stated above, negative and cognitive symptoms can cause significant impairment to a patient's everyday life. ${ }^{15}$ Creating treatments that target the alleviation of these symptoms may help to improve patients' daily functioning and overall quality of life. It is possible that targeting the $5-\mathrm{HT}_{2 \mathrm{~A}}$ serotonin receptors and developing drugs that are more specific to $5-\mathrm{HT}_{2 \mathrm{~A}}$ receptors can significantly affect these symptoms. ${ }^{11}$ Lumateperone tosylate is a new secondgeneration antipsychotic indicated for treating schizophrenia that can potentially alleviate positive and negative symptoms. ${ }^{16}$ This drug interacts with dopamine, serotonin, and glutamate, making it unique compared to other antipsychotics. ${ }^{17}$ Its highly selective nature for $\mathrm{D}_{2} \mathrm{R}$ receptors in specific brain regions decreases unfavorable adverse effects and makes it a safer drug. ${ }^{16}$

\section{SCHIZOPHRENIA EPIDEMIOLOGY/ PATHOPHYSIOLOGY/RISK FACTORS/ PRESENTATION}

Schizophrenia is a severe mental disorder that can cause severe impairment to cognition and perception. The term was coined in the early 1900s and means "to split the mind." Schizophrenia affects approximately $1 \%$ of the world's population but can vary geographically. ${ }^{18}$ The disorder can manifest differently in individual patients, with some patients having only a few acute episodes to others having recurrent episodes with symptoms that worsen over time. ${ }^{19}$ Additionally, patients have a $4.9 \%$ higher risk of committing suicide than the general population. ${ }^{20}$ Schizophrenia is more prevalent in lower socio-economic groups. ${ }^{19} \mathrm{Al}$ though the disorder generally manifests during early adulthood, there is evidence that the development of schizophrenia can begin during neurodevelopment. ${ }^{21}$ Cognitive impairment can present in individuals before they are diagnosed in early adulthood. ${ }^{22}$ Children can present with neurologic development impairment, such as attention deficits and motor function problems. ${ }^{23}$ Overall, there are several risk factors, both environmental and genetic, that can contribute to the development of schizophrenia.

Environmental risk factors that have been linked to the development of schizophrenia can be tied to incidences during the prenatal period, childhood, adolescence, and early adulthood. ${ }^{24}$ Experiencing complications during pregnancy or birth can cause an increased risk for an individual to develop schizophrenia. ${ }^{25}$ Some complications include diabetes, pre-eclampsia, abnormal fetal development, and complications during delivery such as asphyxia. ${ }^{26}$ Additionally, a disproportionate number of patients with schizophrenia were born in the winter and late spring. ${ }^{27}$ There is about a $10 \%$ increase in the incidence of individuals with schizophrenia born in the winter versus the summer. ${ }^{28}$ This may be due to an increase in respiratory tract infections and influenza during the winter months. Mothers who contract the influenza virus during their second trimester of pregnancy are at an increased risk of having a child with schizophrenia. ${ }^{29}$ Other risk factors include a vitamin D deficiency from insufficient sunlight or a folic acid deficiency from an inadequate diet. ${ }^{5}$ Another environmental risk factor is paternal age, as older fathers are at a higher risk of having a child with schizophrenia. ${ }^{30}$ The group at the highest risk are those with the paternal age of 55 years or older. ${ }^{31}$ However, further studies have shown that older paternal age is only relevant in individuals with a family history of schizophrenia, meaning there could be potential additional biologic factors. ${ }^{32}$ Trauma, death of a parent, and infection during childhood can also lead to an increased risk of developing schizophrenia. ${ }^{33}$ Children who experienced significant stress and hardships are also at a higher risk. ${ }^{34}$ There is some debate whether the use of cannabis during adolescence is associated with a higher risk of developing the disorder. Some studies have shown that individuals who have used cannabis are 2 to 25 times more likely to develop schizophrenia. ${ }^{35}$ However, other studies have shown that the use of this drug only affects individuals who are already vulnerable to the disorder. ${ }^{36}$ Other illicit drugs, such as amphetamines and cocaine, can produce psychotic episodes similar to schizophrenia. ${ }^{37}$ Individuals who are raised in an urban environment are also at a higher risk of developing schizophrenia. 1

There is also a genetic component to the development of schizophrenia, as having an affected family member dramatically increases the risk of developing the disorder. Mul- 
tiple twin studies have been done to show the genetic aspect of schizophrenia. Dizygotic twins, who share $50 \%$ of their DNA, have a lower risk of both twins developing schizophrenia than monozygotic twins, who share $100 \%$ of their DNA. ${ }^{38}$ Heritability of the disorder is estimated to be about $80 \% .{ }^{39}$ If one parent has schizophrenia, the probability that they will pass it down to their child is $13 \%$, and if both parents are affected, the probability is more than $20 \% .{ }^{19}$ It is hard to tell if an abnormality in specific genes can cause the development of schizophrenia. However, there are structural abnormalities of particular chromosomes that have been tied to an increased risk of developing schizophrenia. ${ }^{40}$ Some abnormalities that have been recorded are a deletion of several megabases of chromosome 22q11.2 and the balanced reciprocal translocation of chromosomes 1q42/11q14. ${ }^{41}$ The deletion on chromosome 22q11.2 has been linked to a $30 \%$ to $40 \%$ increased risk of developing schizophrenia. ${ }^{42}$ Linkage analysis has also been done to find the relationship between specific genes located close to each other on a chromosome. ${ }^{43}$ These genes are sometimes inherited together during meiosis. Using this data, "candidate genes" that may have a role in the pathogenesis of schizophrenia have been identified. ${ }^{43}$ Some include DISC1, DNTNBP1, NRG1, and COMT. ${ }^{43}$ However, there is still conflicting evidence, and the topic remains widely debated.

So far, the pathogenesis of schizophrenia can be thought of as being due to a combination of environmental and genetic risk factors. These factors disrupt brain development and can lead to some of the symptoms of schizophrenia. ${ }^{22}$ Postmortem studies have shown that patients with schizophrenia have "lower levels of synaptic proteins, dendritic spines and gamma-aminobutyric acid (GABA)." 44 Abnormal GABAergic function has been primarily associated with patients who have schizophrenia. ${ }^{45}$ Reduced GABA activity can be due to the downregulation of a gene that encodes the enzyme for GABA synthesis, glutamate decarboxylase I (GAD1). ${ }^{46}$ Abnormal dopamine receptor activity has also been recorded in individuals with schizophrenia. There is some evidence that these patients have an increased expression of dopamine receptors in the striatum region of their brain. ${ }^{47}$ Current antipsychotic drugs are dopaminolytic, while dopamine agonists can cause psychosis. ${ }^{1}$ Negative and cognitive symptoms may present well before the onset of the first psychotic episode. ${ }^{48}$ As stated, schizophrenia generally develops in individuals during early adulthood, and it is positive symptoms that usually cause an individual to seek clinical assistance. However, cognitive and negative symptoms may manifest during childhood as apathy or attention and memory deficits. The creation of synaptic connections during childhood and subsequent synaptic pruning during adolescence usually are developmental events that happen in an individual's lifetime. ${ }^{49}$ These processes are known to be disrupted in patients with schizophrenia, leading to abnormal neural communication and loss of grey matter. ${ }^{50,51}$ Synchronized neural oscillations are associated with cognitive processes and are tied to functional networks in healthy individuals. ${ }^{52}$ In patients with schizophrenia, these oscillations are disrupted and can lead to the cognitive and negative symptoms experienced by these individuals. ${ }^{53}$ The disrupted balance of excitatory and inhibitory neurons can also lead to these symptoms, caused in part by the decrease in dendritic spines mentioned previously. ${ }^{54}$ Additionally, abnormal serotonin levels can lead to an increased risk of developing schizophrenia. ${ }^{55}$ Serotonin affects multiple other neurotransmitters such as glutamate, GABA, and acetylcholine, altering their activity. ${ }^{56}$ One serotonin receptor, serotonin 2A receptor (HTR2A), has been linked to the pathophysiology of schizophrenia. ${ }^{57}$ Studies have shown that the expression of this receptor can change over time in patients with schizophrenia. ${ }^{58}$ The development of drugs that target this receptor may eventually provide the path to the treatment of schizophrenia.

\section{CURRENT TREATMENT OF SCHIZOPHRENIA}

\section{FIRST-GENERATION ANTIPSYCHOTICS}

First-generation antipsychotics (FGA) drugs act by blocking dopamine $\mathrm{D}_{2}$ receptors in the central nervous system to reduce the positive symptoms of schizophrenia and reduce the risk of relapse. FGAs do not express selective binding for dopamine receptors in the CNS, and this lack of specificity causes a range of side effects, most notably extrapyramidal symptoms (EPS). ${ }^{59}$ The binding affinity of these drugs for $\mathrm{D}_{2}$ receptors is strongly associated with their therapeutic doses. ${ }^{60}$ In vitro studies show that high potency FGAs, like haloperidol, bind stronger to $\mathrm{D}_{2}$ receptors and dissociate more slowly than low potency FGAs. ${ }^{61}$ Moreover, studies have shown that antipsychotic effects are achieved with $65-70 \% \mathrm{D}_{2}$ receptor occupancy, but a $\mathrm{D}_{2}$ occupancy greater than $80 \%$ markedly increases the risk of EPS. ${ }^{62,63}$ Also, studies have shown that approximately $30 \%$ of patients with acute symptoms have little or no response to FGAs, and up to $50 \%$ of patients only show a weak or partial response. ${ }^{64}$ Furthermore, FGAs offer little benefit for the negative symptoms or cognitive impairment seen in schizophrenia patients; high doses of FGAs may exacerbate negative symptoms and worsen cognitive impairment by blocking dopamine receptors in the mesocortical pathway. ${ }^{59,65}$ Due to the risk of severe EPS, FGAs are preferred for patients that have a history of a positive response and tolerable side effects to the drugs.

\section{SECOND-GENERATION ANTIPSYCHOTICS}

Second-generation antipsychotics (SGA) are currently the preferred treatment for schizophrenia. SGAs were revolutionary as they can markedly decrease the positive and negative symptoms seen in schizophrenia patients while not producing the EPS seen in patients taking FGAs. ${ }^{59,66}$ In comparison to the typical antipsychotics that selectively block dopamine $\mathrm{D}_{2}$ receptors, SGAs act on dopamine receptors and act on serotonin receptors, mainly $5-\mathrm{HT}_{2 \mathrm{~A}}$ receptors. ${ }^{59,67}$ Clozapine was the first SGA developed and used in clinical practice, and many newer SGAs have been developed based on the structure of clozapine. ${ }^{66}$ All of the SGAs have unique pharmacologic properties, but they all principally have antagonistic activity on dopaminergic $\mathrm{D}_{2}$ and serotoninergic $5-\mathrm{HT}_{2 \mathrm{~A}}$ receptors. SGAs can be divided into groups based on binding affinity for $\mathrm{D}_{2}$ and $5-\mathrm{HT}_{2 \mathrm{~A}}$ receptors, SGAs with modest binding affinity, such as clozapine and olanzapine, and SGAs with high affinity, such as 
risperidone and lurasidone. ${ }^{68}$ There is significant evidence that antagonistic effects on $5-\mathrm{HT}_{2 \mathrm{~A}}$ receptors seen in SGAs contribute to the decreased risk of producing EPS compared to FGAs. Meltzer et al. suggest that an SGA will show increased atypical antipsychotic effects if it has a higher affinity for $5-\mathrm{HT}_{2 \mathrm{~A}}$ receptors relative to $\mathrm{D}_{2}$ receptors. ${ }^{69}$ Furthermore, this principle can explain the enhanced efficacy and reduced EPS of SGAs compared to FGAs. ${ }^{70}$

\section{SYSTEMATIC REVIEWS}

In 2016, a randomized, double-blind, placebo-controlled, and active-controlled trial-tested lumateperone against risperidone and a placebo in 335 acutely psychotic adults with schizophrenia. ${ }^{71}$ Risperidone, the active control, as compared to two doses of lumateperone and a placebo group. ${ }^{71}$ After the 28-day study, lumateperone showed a statistically and clinically significant reduction in symptoms, measured by PANSS total score, at a dose of $60 \mathrm{mg}$ but showed no distinction from the placebo group at $120 \mathrm{mg} .{ }^{11}$ In a randomized, double-blind, placebo-controlled, phase 3 clinical trial of 450 patients with acute exacerbation of schizophrenia, lumateperone demonstrated an ability to reduce symptoms without producing clinically significant adverse effects. ${ }^{72}$ A $42 \mathrm{mg}$ dose of lumateperone has shown statistically significant differences in reducing symptoms of schizophrenia without producing clinically significant motor, cardiometabolic, or endocrine adverse effects compared with the placebo. ${ }^{72}$

\section{LUMATEPERONE TOSYLATE DRUG INFORMATION}

Lumateperone (CAPLYTA) is a newly FDA-approved, firstin-class drug used for the treatment of schizophrenia. It is available in $42 \mathrm{mg}$ capsules for a once-daily recommended dose. In November 2017, the U.S. Food and Drug Administration (FDA) granted fast-track designation for lumateperone to treat schizophrenia. Lumateperone received approval in the USA to treat schizophrenia in adults in December 2019. ${ }^{73}$ The most common adverse effects are mild, such as somnolence, constipation, sedation, and fatigue with the $42 \mathrm{mg}$ recommended dose. ${ }^{72}$ Serious adverse events include orthostatic hypotension, hyperglycemia, dyslipidemia, leukopenia, neutropenia, extrapyramidal disease, neuroleptic malignant syndrome, and tardive dyskinesia. ${ }^{74}$ The drug has a black-box warning for elderly patients with dementia-related psychosis who are at an increased risk for a serious cerebrovascular accident when taking the medication; lumateperone is not approved to treat patients with dementia-related psychosis. ${ }^{73}$ It is contraindicated in patients with known hypersensitivity reactions to lumateperone (Caplyta FDA Label). Also, patients taking CYP3A4 inducers or moderate to potent CYP3A4 inhibitors are advised to avoid lumateperone. ${ }^{72}$ Lumateperone may react with alcohol and other sedatives to produce sedation. Lumateperone does not have FDA approval as an "add-on" treatment for patients prescribed another antipsychotic with residual symptoms.

\section{MECHANISM OF ACTION}

Lumateperone is a selective and concurrent modulator of serotonin, dopamine, and glutamate, which are all involved with serious mental illness. Lumateperone is selective for $\mathrm{D}_{2}$ receptors and acts as a dopamine receptor phosphoprotein modulator (DPPM). ${ }^{75}$ It acts as a presynaptic partial agonist and postsynaptic antagonist at $\mathrm{D}_{2}$ receptors. ${ }^{75}$ This novel action causes reduced presynaptic release of dopamine and blockade of postsynaptic dopamine activity, allowing for marked reduction of dopaminergic signaling. ${ }^{75}$ Lumateperone shows selectivity for the mesocortical and mesolimbic pathways receptors and has a decreased affinity for the receptors of nigrostriatal pathways. ${ }^{16,76}$ Lumateperone also acts as an antagonist of serotonin $5-\mathrm{HT}_{2 \mathrm{~A}}$ receptors and has a 60 -fold higher affinity for $5-\mathrm{HT}_{2 \mathrm{~A}}$ receptors than D2 receptors. ${ }^{71,77}$ Moreover, it acts as an inhibitor of the serotonin reuptake transporter (SERT), potentially causing antidepressant effects while reducing some of the negative symptoms of schizophrenia, such as depression. ${ }^{16,78}$ Lumateperone modulates glutaminergic activity by increasing the phosphorylation of mesolimbic GluN2B subunits of NMDA receptors, enhancing glutamatergic NMDA function. ${ }^{78}$ This augmentation of NMDA receptors may contribute to the drug's effects as an antipsychotic and antidepressant as NMDA receptor activity is insufficient in schizophrenic patients. ${ }^{78}$ Lumateperone has shown fewer adverse effects than other antipsychotics, as it does not interact with the muscarinic and histaminergic receptors that contribute to common adverse effects that occur with other antipsychotic drugs. ${ }^{78}$ The pharmacological actions of the drug mainly cause sedation and reduction of agitation and aggression at lower doses while showing antipsychotic and antidepressant effects at higher doses. ${ }^{77}$ The effects of lumateperone seen at low dosages may result from its lack of $\mathrm{D}_{2}$ receptor binding and favored $5-\mathrm{HT}_{2 \mathrm{~A}}$ receptor antagonism at low dosages. Increasing the dose allows for $\mathrm{D}_{2}$ receptor binding in addition to $5-\mathrm{HT}_{2 \mathrm{~A}}$ receptor binding, resulting in antipsychotic effects. ${ }^{16}$

\section{PHARMACOKINETICS/PHARMACODYNAMICS}

\section{ABSORPTION AND DISTRIBUTION}

Lumateperone is absorbed rapidly in the G.I. tract with peak concentration $\left(\mathrm{C}_{\max }\right)$ occurring at approximately 1 hour $\left(\mathrm{T}_{\max }\right)$, after the once-daily oral administration of $42 \mathrm{mg}$ capsule, in the fasted state. ${ }^{72,74}$ Ingestion of a high-fat meal leads to an approximate decrease in $\mathrm{C}_{\text {max }}$ of $33 \%$, and $\mathrm{T}_{\max }$ is extended to approximately 2 hours. ${ }^{73,79}$ Dosages at $120 \mathrm{mg} /$ day have not been shown to produce any statistically significant improvement in efficacy. When taken with a high-fat meal, the area under the plasma-concentration-time curve (AUC) increases by $9 \% .{ }^{73}$ Steady-state is achieved in about five days, and the half-life of the drug is 13 to 21 hours. The volume of distribution of lumateperone is approximately $4.1 \mathrm{~L} / \mathrm{kg}$ following intravenous administration. ${ }^{72}$ The drug is $97.4 \%$ bound to plasma proteins with a bioavailability of $4.4 \%$ when taken orally. ${ }^{74}$ 


\section{METABOLISM}

Lumateperone is extensively metabolized in the liver through multiple enzyme systems yielding over 20 metabolites. However, lumateperone is predominantly metabolized via ketone reductases, the CYP3A system, and UGT enzymes. ${ }^{16,71,73}$ Following a single oral dose of radiolabeled lumateperone, lumateperone, and its glucuronidated metabolites represent approximately 2.8 and $51 \%$ of the total plasma radioactivity. ${ }^{73}$ Because of this metabolic profile, various drug interactions are observed. Patients taking CYP3A4 inducers should avoid the use of lumateperone, as coadministration will decrease the exposure of lumateperone. ${ }^{71}$ Concomitant administration of lumateperone with moderate or potent CYP3A4 inhibitors should be avoided as increased lumateperone exposure may increase the risk of toxicity. ${ }^{72}$ Also, the use of lumateperone with UGT inhibitors should be avoided as coadministration can lead to increased exposure of lumateperone and its metabolites. ${ }^{79}$

\section{ELIMINATION}

When taken orally, $58 \%$ radiolabeled lumateperone is excreted in the urine, and $29 \%$ is excreted in the feces. ${ }^{79}$ Less than $1 \%$ of the dose is excreted in the urine unchanged. ${ }^{73,79}$ The metabolites of lumateperone are water-soluble. Thus they are entirely excreted in the urine. ${ }^{16}$ Lumateperone has a total body clearance of $27.9 \mathrm{~L} / \mathrm{h}$ with IV administration. ${ }^{74}$

\section{SAFETY AND EFFICACY}

\section{PHASE I CLINICAL TRIALS}

Single doses of lumateperone (ITI-007) were given to healthy male volunteers and were safe and well-tolerated with no serious adverse effects (A.E.s). No clinically significant time or dose-related variations were seen in laboratory or cardiovascular parameters.

In another phase I clinical trial, healthy volunteers were given once-daily oral doses of ITI-007 for five days and determined to be safe and well-tolerated. In part 2 of the study, patients with schizophrenia were given once-daily oral doses of ITI-007 for five days. The drug was safe and well-tolerated in this patient population as well.

In both trials, there were no clinically relevant changes noted in vital signs, ECG, laboratory tests, or physical exams. No dose-limiting side effects observed. ${ }^{71}$

\section{PHASE II CLINICAL TRIALS}

FDA approval was given for lumateperone for the treatment of schizophrenia based on two randomized, double-blind, placebo-controlled trials: a phase II trial (ITI-007-500; NCT01499563) and a phase III trial (ITI-007-301; NCT00282761). ${ }^{79}$ In ITI-007-500; NCT01499563, patients ranging in age from 18-55 years with acute exacerbation of psychosis were given $60 \mathrm{mg}$ ITI-007, $120 \mathrm{mg}$ ITI-007, risperidone $4 \mathrm{mg}$, or placebo once daily for four weeks. The primary endpoint was the measurement of the PNSS total score with secondary analyses performed on symptom subscales. There was a significant difference between $60 \mathrm{mg}$ ITI-007 and placebo in PANSS total score (LSMD -13.2 vs.
-7.4 for placebo; $p=0.017) .4 \mathrm{mg}$ risperidone also showed a significant change when compared to placebo (LSMD -13.4 vs. -7.4 for placebo; $p=0.013$ ). $120 \mathrm{mg}$ ITI-007 did improve positive symptoms and general psychopathology; however, the differences were not significant when compared to placebo. ${ }^{80}$ Both $60 \mathrm{mg}$ of ITI-007 and $4 \mathrm{mg}$ risperidone significantly improved PANSS positive symptoms and PANSS general psychopathology compared to placebo. ${ }^{73}$ Negative symptoms only improved with $60 \mathrm{mg}$ ITI-007; however, this improvement was not significant. Neither $4 \mathrm{mg}$ risperidone or $120 \mathrm{mg}$ ITI-007 showed improvement in negative symptoms. The lack of improvement seen in negative symptoms maybe be due to low negative symptomology at baseline. Of those with prominent negative symptoms at baseline, 60 mg ITI-007 reduced the severity of negative symptoms as measured by the PANSS negative symptom scale (ES 0.34). In the risperidone group, the improvement in negative symptoms was less than in the placebo group. In patients that met the criteria of comorbid symptoms of depression, $60 \mathrm{mg}$ ITI-007 significantly reduced the total PANSS score and CDSS score with an E.S. of $\sim 1$ on both measures. $60 \mathrm{mg}$ ITI-007 significantly improved prosocial behavior measured by the PANSS prosocial factor (ES 0.6). ${ }^{80} 120 \mathrm{mg}$ ITI-007 did not change substantially PANSS scores when compared to placebo. It is unknown why the $120 \mathrm{mg}$ dose showed a lack of efficacy, although it may be attributed to differences in population, measurement errors, or the possibility that the combined effect presynaptic dopamine $\mathrm{D}_{2}$ agonism and postsynaptic $\mathrm{D}_{2}$ antagonism could make the higher dose less effective. ${ }^{71}$

In another phase II study, ten patients ranging in age from 18-60 years old with stable schizophrenia were given $60 \mathrm{mg}$ ITI-007 once daily for two weeks, and $\mathrm{D}_{2}$ receptor occupancy was measured using positron emission tomography. The $\mathrm{D}_{2}$ receptor occupancy for $60 \mathrm{mg}$ ITI-007 was found to be $39 \%$ which is lower than the effective doses of second-generation antipsychotics. This finding may contribute to the favorable safety and tolerability of ITI-007. ${ }^{16}$

\section{PHASE III CLINICAL TRIALS}

In a randomized, double-blind phase III trial (ITI-007-301; NCT00282761), 450 patients ranging in age from 18-60 were randomly assigned to receive one of three treatments: 60 $\mathrm{mg}$ (42 $\mathrm{mg}$ active moiety) ITI-007, $40 \mathrm{mg}$ (28 mg active moiety) ITI-007, or a placebo once daily for four weeks. The primary endpoint was a change in PANSS score from baseline to the end of treatment on day 28 compared to placebo. ${ }^{73}$ The secondary endpoints were the CGI-S score and other secondary efficacy measures, including positive, negative, and psychopathological PANSS subscales, Personal and Social Performance Scale (PSP), PANSS derived prosocial factor, and Calgary Depression Scale for Schizophrenia. ${ }^{72}$ In the intention-to-treat analysis, the least-squares mean change from baseline in the PANSS score upon completion of treatment was -14.5 in the patients who received $42 \mathrm{mg}$ ITI-007 vs. -10.3 in the placebo group. ${ }^{73}$ Statistically significant differences from placebo in the PANSS total score were seen by day 8 of the trial and continued until completion on day 28 in the $42 \mathrm{mg}$ ITI-007 group. Consistent treatment effects were seen amongst subgroups of race, ethnic- 
ity, age, and sex to compare $42 \mathrm{mg}$ ITI-007 and placebo. Those in the $42 \mathrm{mg}$ ITI-007 group also saw a statistically significant change in CGI-S score from baseline compared to placebo (LSMD from placebo -0.3 ; unadjusted $P=0.003$ ). The effects of the $28 \mathrm{mg}$ ITI-007 group were not significant regarding the primary endpoint; however, a significant difference was seen in the CGI-S score compared to placebo (LSMD from placebo -0.2 ; nominal $P=0.02$ ). Both treatment groups showed significant improvements in the PANSS positive symptom from baseline to day 28 compared to placebo (42 mg LSMD -1.7; nominal $\mathrm{P}=0.006$ and 28 mg: LSMD -1.2; nominal $\mathrm{P}=0.04)$. Changes in PANSS negative sub score did not change significantly between baseline and day 28 in either group compared to placebo. When compared to placebo, the $42 \mathrm{mg}$ group showed significant improvements in the general psychopathology subscale score and the psychosocial function as measured by the PANSS derived prosocial factor and PSP scale (general psychopathology subscale: LSMD -2.4 ; nominal $P=0.01$; PANSS derived prosocial factor: LSMD -1.1 ; nominal $P=0.04$; PSP scale: LSMD 3.3; nominal $P=0.05$. Change in Calgary Depression Scale for Schizophrenia from baseline throughout treatment changed significantly in neither the $42 \mathrm{mg}$ ITI-007 nor the $28 \mathrm{mg}$ ITI-007 group when compared to placebo. ${ }^{72}$

In another phase III trial, ITI-302 (NCT02469155), 696 patients with acute schizophrenia were given either $42 \mathrm{mg}$ ITI-007, $14 \mathrm{mg}$ ITI-007, risperidone $4 \mathrm{mg}$, or placebo once daily for a total of 6 weeks. Neither dosage of ITI-007 showed significant changes in PANSS total score when compared to placebo. ${ }^{73}$

\section{POOLED ANALYSES}

A pooled study was conducted by combining ITI-007-301 (NCT00282761), ITI-302 (NCT02469155), and ITI-500 (NCT01499563 ). ${ }^{73}$ The efficacy data were pooled from the two positive studies (ITI-007-005 and ITI-007-301), and safety data was pooled from all three studies. In the efficacy analyses, which included 520 patients, ITI-00742 mg significantly reduced PANSS total score (L.S. mean difference -4.76; $P<0.001) .42 \mathrm{mg}$ ITI-007 showed similar efficacy when compared to $4 \mathrm{mg}$ risperidone (LSMD $-4.97 ; P=0.014$ ). ITI-007 $42 \mathrm{mg}$ also showed significant improvement in CGIS score (LSMD - $0.29 ; P<0.001) .{ }^{81}$

\section{SAFETY}

In a phase II trial (ITI-500; NCT01499563), ITI-007 was safe and well-tolerated in individuals with schizophrenia. There were no serious adverse events in individuals treated with ITI-007. During the trial, five patients discontinued treatment due to an adverse event: one patient who received ITI-007 experienced dry mouth, and one patient who received ITI-007 experienced worsening of schizophrenia. The relative risk of treatment-emergent adverse event (TEAEs) for $60 \mathrm{mg}$ ITI-006 is 1.14 , which does not vary significantly from placebo $(p=0.346)$. The relative risk for $120 \mathrm{mg}$ ITI-007 was 1.3 ( $p=0.024)$. The most frequent adverse event was somnolence and sedation. Neither $60 \mathrm{mg}$ ITI-007 nor $120 \mathrm{mg}$ ITI-007 was associated with extrapyramidal symptoms (EPS). Risperidone caused akathisia in 7\% of subjects. Median weight from day -7 to day 28 was approximately $1 \mathrm{~kg}$ for patients who received placebo, $60 \mathrm{mg}$ ITI-007, and $120 \mathrm{mg}$ ITI-007. Weight gain from day -7 to day 28 was $2.5 \mathrm{~kg}$ for the risperidone group. Placebo adjusted mean weight gain by site indicated a weight gain of 0.3 to 0.4 for both $60 \mathrm{mg}$ ITI-007 and $120 \mathrm{mg}$ ITI-007 and a weight gain of $2.3 \mathrm{~kg}$ for risperidone. Both doses of ITI-007 showed less weight gain when compared to placebo. Both doses of ITI-007 showed significantly lower levels of prolactin, fasting glucose, total cholesterol, and triglycerides. Levels of insulin, glucose, triglycerides, and prolactin remained low through the course of treatment with ITI-007 but increased when switched to the standard of care after the trial period. ${ }^{80}$

In the phase III trial (ITI-007-301; NCT00282761), patients were randomized to receive either $42 \mathrm{mg}$ ITI-007, 28 mg ITI-007, or a placebo once daily for four weeks. TEAEs occurred in $64.7 \%$ of patients in the $42 \mathrm{mg}$ lumateperone group, $56.7 \%$ of the $28 \mathrm{mg}$ ITI-007 group, and $50.3 \%$ of the placebo group. TEAEs occurring in either ITI-007 group in greater than $5 \%$ of patients and twice the rate in placebo were somnolence, sedation, fatigue, and constipation. Two patients experienced severe TEAEs and discontinued treatment: one experienced orthostatic hypotension, and one experienced convulsion. No severe or adverse drug effects were reported throughout the study. Neither treatment option of ITI-007 was associated with increased EPS. The median change in weight from baseline to day 28 was $0.9 \mathrm{~kg}$ for $42 \mathrm{mg}$ ITI-007, $0.6 \mathrm{mg}$ for $28 \mathrm{mg}$, and $0.7 \mathrm{~kg}$ for placebo. No significant changes were seen in metabolic parameters, physical exam results, vital signs, or ECG findings. ${ }^{72}$

Lumateperone comes with a black box warning because elderly patients with dementia-related psychosis treated with antipsychotics are at an increased risk of death. As a result, lumateperone is not approved to treat patients with dementia-related psychosis. The only contraindication for the use of lumateperone is a hypersensitivity to the drug. Monitoring is recommended for orthostatic hypotension, metabolic and endocrine abnormalities such as hyperglycemia, dyslipidemia, weight gain, and body temperature dysregulation. Patients on lumateperone are at an increased risk for falls due to somnolence, postural hypotension, and motor and sensory instability; thus, monitoring is recommended. Esophageal dysmotility and aspiration may occur in patients on antipsychotics. Hematologic abnormalities such as leukopenia and neutropenia may occur in patients with pre-existing low WBC or neutrophil counts or a history of drug-induced leukopenia or neutropenia. Therefore, CBC during the first few months of treatment is recommended. Fetal risk in pregnant mothers and infant risk in breastfeeding cannot be ruled out. A toxic dose has not been established, nor has overdose been reported with the use of lumateperone. It is recommended that adults take an oral $42 \mathrm{mg}$ dose once daily with food, with no requirement for dose titration. Safety and efficacy in patients has not been established in pediatric patients. ${ }^{74}$

Nonadherence to medication in the treatment of schizophrenia is primarily due to adverse effects. Since the 2000s, the second-generation antipsychotics that have been introduced have lower rates of sedation, metabolic, and endocrine adverse effects; however, they are not without com- 
Table 1. Safety and Efficacy

\begin{tabular}{|c|c|c|c|}
\hline $\begin{array}{l}\text { Author } \\
\text { (Year) }\end{array}$ & Groups Studied and Intervention & Results and Findings & Conclusions \\
\hline $\begin{array}{l}\text { Study 1: } \\
\text { Davis and } \\
\text { Correll }^{71}\end{array}$ & $\begin{array}{l}\text { In a phase I trial, single oral doses } \\
\text { ranging from } 2.5-30 \mathrm{mg} \text { of ITI-007 } \\
\text { were given to } 30 \text { healthy male } \\
\text { volunteers. }\end{array}$ & $\begin{array}{l}\text { Oral doses were safe and tolerated with no } \\
\text { serious adverse effects or clinically significant } \\
\text { time or dose-related changes in laboratory or } \\
\text { cardiovascular parameters. }\end{array}$ & $\begin{array}{l}\text { ITI-007 has a } \\
\text { favorable } \\
\text { safety and } \\
\text { tolerability } \\
\text { profile in } \\
\text { healthy } \\
\text { patients }\end{array}$ \\
\hline $\begin{array}{l}\text { Study 2: } \\
\text { Davis and } \\
\text { Correll71 }\end{array}$ & $\begin{array}{l}\text { In a phase I trial, } 18 \text { healthy } \\
\text { volunteers were given once-daily oral } \\
\text { doses of ITI-007 ranging from } 5-20 \\
\text { mg for } 5 \text { days. In another group, } 34 \\
\text { patients with stable schizophrenia } \\
\text { were given once-daily oral doses of } \\
\text { ITI-007 ranging from } 30-140 \mathrm{mg} \text { for } \\
5 \text { days. }\end{array}$ & $\begin{array}{l}\text { Doses were safe and well-tolerated in both trial } \\
\text { groups with no clinically relevant dose-related } \\
\text { changes in lab tests, vitals, or cardiovascular } \\
\text { parameters. }\end{array}$ & $\begin{array}{l}\text { ITI-007 has a } \\
\text { favorable } \\
\text { safety and } \\
\text { tolerability } \\
\text { profile in } \\
\text { healthy } \\
\text { patients and } \\
\text { patients with } \\
\text { schizophrenia }\end{array}$ \\
\hline $\begin{array}{l}\text { Study 3: } \\
\text { Lieberman } \\
\text { et al. } .80\end{array}$ & $\begin{array}{l}\text { In phase II randomized, double-blind, } \\
\text { placebo-controlled trial, } 335 \text { acutely } \\
\text { psychotic adults with schizophrenia } \\
\text { were randomized to receive } 60 \mathrm{mg} \\
\text { ITI-007, } 120 \mathrm{mg} \text { ITI-007, } 4 \mathrm{mg} \\
\text { risperidone, or placebo once daily for } \\
28 \text { days }\end{array}$ & $\begin{array}{l}60 \mathrm{mg} \text { ITI-007 and } 4 \mathrm{mg} \text { risperidone } \\
\text { demonstrated efficacy over placebo as shown in } \\
\text { improved PANSS total score. } 60 \mathrm{mg} \text { ITI-007 also } \\
\text { showed improvements in negative and } \\
\text { depressive symptoms. } 120 \mathrm{mg} \text { ITI-007 did not } \\
\text { show any significant changes when compared to } \\
\text { placebo. Both doses of ITI-007 were well } \\
\text { tolerated }\end{array}$ & $\begin{array}{l}60 \mathrm{mg} \text { ITI-007 } \\
\text { was effective } \\
\text { for treatment } \\
\text { of } \\
\text { schizophrenia } \\
\text { and showed no } \\
\text { differences } \\
\text { from placebo } \\
\text { on safety } \\
\text { measures. }\end{array}$ \\
\hline $\begin{array}{l}\text { Study 4: } \\
\text { Correll et } \\
\text { al. }{ }^{72}\end{array}$ & $\begin{array}{l}\text { In phase II randomized, double-blind, } \\
\text { placebo-controlled trial, acutely } \\
\text { psychotic patients with } \\
\text { schizophrenia were given either } 60 \\
\text { ( } 42 \mathrm{mg} \text { active moiety) mg ITI-007, } 40 \\
\mathrm{mg}(28 \mathrm{mg} \text { active moiety) ITI-007, or } \\
\text { placebo once daily for } 4 \text { weeks }\end{array}$ & $\begin{array}{l}60 \mathrm{mg} \text { significantly improved PANSS total score } \\
\text { from baseline to day } 28 \text { when compared to } \\
\text { placebo. Both doses of ITI-007 were safe and } \\
\text { well-tolerated }\end{array}$ & $\begin{array}{l}60 \mathrm{mg} \text { ITI-007 } \\
\text { showed } \\
\text { efficacy in } \\
\text { treating the } \\
\text { symptoms of } \\
\text { schizophrenia. } \\
\text { Both doses of } \\
\text { ITI-007 had a } \\
\text { favorable } \\
\text { safety profile }\end{array}$ \\
\hline
\end{tabular}

plications. Asenapine causes weight gain and sedation, but still relatively less than other antipsychotics such as olanzapine or quetiapine. Partial agonists such as aripiprazole, brexpiprazole, and cariprazine cause akathisia. Lurasidone is known to cause dose-dependent EPS and akathisia, and iloperidone is known to cause orthostasis. In a meta-analysis of oral antipsychotics, the differences in efficacy between medications are small; however, the side effects vary greatly. Novel medications like lumateperone have so far shown a favorable tolerability profile with minimal risk for adverse events and no need for titration. ${ }^{82}$ Table 1 summarizes the studies discussed in this section.

\section{CONCLUSION}

Schizophrenia is a mental disorder that disrupts the way an individual thinks, feels, and perceives reality. Symptoms can be classified as positive, negative, or cognitive Positive symptoms are abnormal behaviors such as hallucinations, confused thoughts, and delusions. Negative symptoms are the absence of certain behaviors, such as isolating oneself or lack of emotion. Cognitive symptoms are cognition impairments such as reduced memory capacity or learning disabilities. The onset of schizophrenia occurs later in females than in males, affecting around $1 \%$ of the population. Schizophrenia is thought to be caused by a mixture of environmental and genetic factors. Environmental factors include complications during pregnancy and birth, vitamin D deficiency, parental age, childhood stress, and drug use. Genetic factors include having a relative that has schizophrenia and chromosomal mutations.

Antipsychotics are the drug of choice for the treatment of schizophrenia. First-generation antipsychotics (FGA) drugs block dopamine $\mathrm{D}_{2}$ receptors non-selectively. The non-selective nature of these drugs can cause a range of side effects in the patient. FGAs have low efficacy and may exacerbate negative and cognitive symptoms of schizophrenia. Second-generation antipsychotics (SGA) drugs selectively block dopamine $\mathrm{D}_{2}$ receptors and serotonin $5-\mathrm{HT}_{2 \mathrm{~A}}$ receptors and are the preferred treatment for schizophrenia. SGAs have an increased efficacy compared to FGAs and decrease positive and negative symptoms in patients. Examples SGAs include clozapine, olanzapine, risperidone, and lurasidone.

Lumateperone is a newly approved drug in the treatment of schizophrenia. In a 2016 clinical trial, Lumateperone markedly decreased symptoms of schizophrenia when com- 
pared to risperidone. In 2019, the FDA approved a $42 \mathrm{mg}$ dose to be taken once daily. Lumateperone is contraindicated in patients with hypersensitivity to the drug, elders with dementia-related psychosis, and patients who take CYP3A4 inhibitors. Lumateperone is selective for dopamine $\mathrm{D}_{2}$ receptors and inhibits serotonin $5-\mathrm{HT}_{2 \mathrm{~A}}$ receptors as well as serotonin reuptake transporter. This drug can cause antidepressant effects as well as cause a decrease in negative symptoms.

During phase I of the clinical trial, Lumateperone was given to both healthy and individuals with schizophrenia for five days. No serious adverse effects occurred. In phase II, patients with acute exacerbation of psychosis were given either $60 \mathrm{mg}$ Lumateperone, $120 \mathrm{mg}$ Lumateperone, risperidone $4 \mathrm{mg}$, or a placebo once daily for four weeks. The 60 mg dose reduced negative symptoms and improved prosocial behavior as measured by the PANSS score. There was no significant change in the PANSS score with the $120 \mathrm{mg}$ dose. In phase III, patients were given either $42 \mathrm{mg}$ Lumateperone, $28 \mathrm{mg}$ Lumateperone, or a placebo daily for four weeks. Both doses showed an improvement in positive symptoms using the PANSS scale, but only the $42 \mathrm{mg}$ dose showed a significant improvement in negative symptoms. No seri- ous or adverse effects were reported in phases II or III of the clinical trial. Overall, Lumateperone has so far shown to cause fewer negative side effects than other antipsychotics that are currently in use.

\section{AUTHOR CONTRIBUTIONS}

K Maini, H Gould, V Bollich, andJ LaForge were responsible for writing. A Edinoff, J Fort, AM Kaye, E Cornett, and AD Kaye were responsible for editing.

\section{FUNDING}

No funding was received for this article

\section{CONFLICTS OF INTEREST STATEMENT}

None of the authors of this manuscript have any conflicts of interest

Submitted: June 01, 2021 EST, Accepted: June 16, 2021 EST 


\section{REFERENCES}

1. Kahn RS, Sommer IE, Murray RM, et al. Schizophrenia. Nature Reviews Disease Primers. 2015;1. doi:10.1038/nrdp.2015.67

2. Strauss GP, Sandt AR, Catalano LT, Allen DN. Negative symptoms and depression predict lower psychological well-being in individuals with schizophrenia. Comprehensive Psychiatry. 2012;53(8):1137-1144. doi:10.1016/j.comppsych.201 $\underline{2.05 .009}$

3. Nuechterlein KH, Barch DM, Gold JM, Goldberg TE, Green MF, Heaton RK. Identification of separable cognitive factors in schizophrenia. In: Schizophrenia Research. Vol 72. Schizophr Res; 2004:29-39. doi:10.1 016/j.schres.2004.09.007

4. Provencher HL, Mueser KT. Positive and negative symptom behaviors and caregiver burden in the relatives of persons with schizophrenia. Schizophrenia Research. 1997;26(1):71-80. doi:10.1016/S0920-996 4(97)00043-1

5. Kahn RS, Keefe RSE. Schizophrenia is a cognitive illness: Time for a change in focus. JAMA Psychiatry. 2013;70(10):1107-1112. doi:10.1001/jamapsychiatry.2 $\underline{013.155}$

6. Hafner H, Maurer K, Loffler W, et al. The epidemiology of early schizophrenia. Influence of age and gender on onset and early course. In: British Journal of Psychiatry. Vol 164. Royal College of Psychiatrists; 1994:29-38. doi:10.1192/s00071250002 $\underline{92714}$

7. Saha S, Chant D, Welham J, McGrath J. A systematic review of the prevalence of schizophrenia. PLoS Medicine. 2005;2(5):0413-0433. doi:10.1371/journal.p med.0020141

8. Laursen TM, Nordentoft M, Mortensen PB. Excess Early Mortality in Schizophrenia. Annual Review of Clinical Psychology. 2014;10(1):425-448. doi:10.1146/a nnurev-clinpsy-032813-153657

9. Harvey PD. Assessing disability in schizophrenia: tools and contributors. The Journal of clinical psychiatry. 2014;75(10):e27. doi:10.4088/ICP.13049tx5 $\underline{c}$

10. Green MF, Hellemann G, Horan WP, Lee J, Wynn JK. From perception to functional outcome in schizophrenia: Modeling the role of ability and motivation. Archives of General Psychiatry. 2012;69(12):1216-1224. doi:10.1001/archgenpsychiat ry.2012.652
11. Jones MT, Strassnig MT, Harvey PD. Emerging 5-HT receptor antagonists for the treatment of Schizophrenia. Expert Opinion on Emerging Drugs. 2020;25(2):189-200. doi:10.1080/14728214.2020.1773 $\underline{792}$

12. Kapur S, Remington G. Dopamine D2 receptors and their role in atypical antipsychotic action: Still necessary and may even be sufficient. In: Biological Psychiatry. Vol 50. Biol Psychiatry; 2001:873-883. do $\mathrm{i}: 10.1016 /$ S0006-3223(01)01251-3

13. Lieberman JA, Scott Stroup T, McEvoy JP, et al. Effectiveness of antipsychotic drugs in patients with chronic schizophrenia. New England Journal of Medicine. 2005;353(12):1209-1223. doi:10.1056/NEJM oa051688

14. Meftah AM, Deckler E, Citrome L, Kantrowitz JT. New discoveries for an old drug: a review of recent olanzapine research. Postgraduate Medicine. 2020;132(1):80-90. doi:10.1080/00325481.2019.17018 23

15. Strauss GP, Cohen AS. A Transdiagnostic Review of Negative Symptom Phenomenology and Etiology. Schizophrenia Bulletin. 2017;43(4):712-729. doi:10.109 3/schbul/sbx066

16. Vyas P, Hwang BJ, Brašić JR. An evaluation of lumateperone tosylate for the treatment of schizophrenia. Expert Opinion on Pharmacotherapy. 2020;21(2):139-145. doi:10.1080/14656566.2019.1695 $\underline{778}$

17. Ceskova E, Silhan P. Novel treatment options in depression and psychosis. Neuropsychiatric Disease and Treatment. 2018;14:741-747. doi:10.2147/NDT.S1 $\underline{57475}$

18. McGrath J, Saha S, Chant D, Welham J. Schizophrenia: A concise overview of incidence, prevalence, and mortality. Epidemiologic Reviews. 2008;30(1):67-76. doi:10.1093/epirev/mxn001

19. Epidemiology and risk factors of schizophrenia. PubMed. Accessed July 26, 2020. https://pubmed.ncb i.nlm.nih.gov/26994378/

20. Palmer BA, Pankratz VS, Bostwick JM. The lifetime risk of suicide in schizophrenia: A reexamination. Archives of General Psychiatry. 2005;62(3):247-253. doi:10.1001/archpsyc.62.3.247

21. Murray RM, Lewis SW. Is schizophrenia a neurodevelopmental disorder? BMJ. 1988;296(6614):63-63. doi:10.1136/bmj.296.6614.63 
22. McCutcheon RA, Reis Marques T, Howes OD. Schizophrenia - An Overview. JAMA Psychiatry. 2020;77(2):201-210. doi:10.1001/jamapsychiatry.201 $\underline{9.3360}$

23. Bramon E, Walshe M, McDonald C, et al. Dermatoglyphics and Schizophrenia: A meta-analysis and investigation of the impact of obstetric complications upon a-b ridge count. Schizophrenia Research. 2005;75(2-3):399-404. doi:10.1016/i.schre $\underline{\text { s.2004.08.022 }}$

24. Mäki P, Veijola J, Jones PB, et al. Predictors of schizophrenia - A review. British Medical Bulletin. 2005;73-74:1-15. doi:10.1093/bmb/ldh046

25. Cannon M, Jones PB, Murray RM. Obstetric complications and schizophrenia: Historical and meta-analytic review. American Journal of Psychiatry. 2002;159(7):1080-1092. doi:10.1176/appi.ajp.159.7.10 $\underline{80}$

26. Leask SJ, Done DJ, Crow TJ. Adult psychosis, common childhood infections and neurological soft signs in a national birth cohort. British Journal of Psychiatry. 2002;181(NOV.):387-392. doi:10.1192/bj p.181.5.387

27. Martínez-Ortega JM, Carretero MD, GutiérrezRojas L, Díaz-Atienza F, Jurado D, Gurpegui M. Winter birth excess in schizophrenia and in nonschizophrenic psychosis: Sex and birth-cohort differences. Progress in Neuro-Psychopharmacology and Biological Psychiatry. 2011;35(7):1780-1784. doi:1 0.1016/j.pnpbp.2011.07.002

28. Davies G, Welham J, Chant D, Torrey EF, McGrath J. A Systematic Review and Meta-analysis of Northern Hemisphere Season of Birth Studies in Schizophrenia. Schizophrenia Bulletin. 2003;29(3):587-593. doi:10.109 3/oxfordjournals.schbul.a007030

29. Brown AS, Schaefer CA, Wyatt RJ, et al. Paternal age and risk of schizophrenia in adult offspring. American Journal of Psychiatry. 2002;159(9):1528-1533. doi:10.1176/appi.ajp.159.9.15 $\underline{28}$

30. Malaspina D, Harlap S, Fennig S, et al. Advancing paternal age and the risk of schizophrenia. Archives of General Psychiatry. 2001;58(4):361-367. doi:10.1001/a rchpsyc.58.4.361

31. Messias EL, Chen CY, Eaton WW. Epidemiology of Schizophrenia: Review of Findings and Myths. Psychiatric Clinics of North America. 2007;30(3):323-338. doi:10.1016/i.psc.2007.04.007
32. Sipos A, Rasmussen F, Harrison G, et al. Paternal age and schizophrenia: A population based cohort study. British Medical Journal.

2004;329(7474):1070-1073. doi:10.1136/bmj.38243.67 $\underline{2396.55}$

33. Morgan C, Fisher H. Environment and schizophrenia: Environmental factors in schizophrenia: Childhood trauma - A critical review. Schizophrenia Bulletin. 2007;33(1):3-10. doi:10.1093/s $\underline{\mathrm{chbul} / \mathrm{sbl053}}$

34. Dvir Y, Denietolis B, Frazier JA. Childhood Trauma and Psychosis. Child and Adolescent Psychiatric Clinics of North America. 2013;22(4):629-641. doi:10.1016/j.c hc.2013.04.006

35. Zammit S, Allebeck P, Andreasson S, Lundberg I, Lewis G. Self reported cannabis use as a risk factor for schizophrenia in Swedish conscripts of 1969: Historical cohort study. British Medical Journal. 2002;325(7374):1199-1201. doi:10.1136/bmj.325.737 $\underline{4.1199}$

36. Boydell J. Risk factors for schizophrenia. Expert Review of Neurotherapeutics. 2001;1(2):183-191. doi:1 $\underline{0.1586 / 14737175.1 .2 .183}$

37. Murray RM, Paparelli A, Morrison PD, Marconi A, Di Forti M. What can we learn about schizophrenia from studying the human model, drug-induced psychosis? American Journal of Medical Genetics, Part B: Neuropsychiatric Genetics. 2013;162(7):661-670. do i:10.1002/ajmg.b.32177

38. Tandon R, Keshavan MS, Nasrallah HA. Schizophrenia, "Just the Facts" What we know in 2008. 2. Epidemiology and etiology. Schizophrenia Research. 2008;102(1-3):1-18. doi:10.1016/j.schres.20 08.04.011

39. Sullivan PF, Kendler KS, Neale MC. Schizophrenia as a Complex Trait: Evidence from a Meta-analysis of Twin Studies. Archives of General Psychiatry. 2003;60(12):1187-1192. doi:10.1001/archpsyc.60.12.1 $\underline{187}$

40. MacIntyre DJ, Blackwood DHR, Porteous DJ, Pickard BS, Muir WJ. Chromosomal abnormalities and mental illness. Molecular Psychiatry. 2003;8(3):275-287. doi:10.1038/sj.mp.4001232

41. Blackwood DHR, Fordyce A, Walker MT, St Clair DM, Porteous DJ, Muir WJ. Schizophrenia and affective disorders - Cosegregation with a translocation at chromosome 1q42 that directly disrupts brain-expressed genes: Clinical and P300 findings in a family. American Journal of Human Genetics. 2001;69(2):428-433. doi:10.1086/321969 
42. Bassett AS, Chow EWC. Schizophrenia and 22q11.2 deletion syndrome. Current Psychiatry Reports. 2008;10(2):148-157. doi:10.1007/s11920-00 8-0026-1

43. Henriksen MG, Nordgaard J, Jansson LB. Genetics of schizophrenia: Overview of methods, findings and limitations. Frontiers in Human Neuroscience. 2017;11. doi:10.3389/fnhum.2017.00322

44. Osimo EF, Beck K, Reis Marques T, Howes OD. Synaptic loss in schizophrenia: a meta-analysis and systematic review of synaptic protein and mRNA measures. Molecular Psychiatry. 2019;24(4):549-561. $\underline{\mathrm{d}}$ oi:10.1038/s41380-018-0041-5

45. Lewis DA. Inhibitory neurons in human cortical circuits: Substrate for cognitive dysfunction in schizophrenia. Current Opinion in Neurobiology. 2014;26:22-26. doi:10.1016/i.conb.2013.11.003

46. Guillozet-Bongaarts AL, Hyde TM, Dalley RA, et al. Altered gene expression in the dorsolateral prefrontal cortex of individuals with schizophrenia. Molecular Psychiatry. 2014;19(4):478-485. doi:10.103 $\underline{8 / \mathrm{mp} .2013 .30}$

47. Kaalund SS, Newburn EN, Ye T, et al. Contrasting changes in DRD1 and DRD2 splice variant expression in schizophrenia and affective disorders, and associations with SNPs in postmortem brain. Molecular Psychiatry. 2014;19(12):1258-1266. doi:10.1 $\underline{038 / \mathrm{mp} .2013 .165}$

48. Piskulic D, Addington J, Cadenhead KS, et al. Negative symptoms in individuals at clinical high risk of psychosis. Psychiatry Research.

2012;196(2-3):220-224. doi:10.1016/j.psychres.2012.0 $\underline{2.018}$

49. Peter R. H. Synaptic density in human frontal cortex - Developmental changes and effects of aging. Brain Research. 1979;163(2):195-205. doi:10.1016/000 $\underline{\text { 6-8993(79)90349-4 }}$

50. Feinberg I. Schizophrenia: Caused by a fault in programmed synaptic elimination during adolescence? Journal of Psychiatric Research. 1982;17(4):319-334. doi:10.1016/0022-3956(82)9003 $\underline{8-3}$

51. Fusar-Poli P, Radua J, McGuire P, Borgwardt S. Neuroanatomical maps of psychosis onset: Voxelwise meta-analysis of antipsychotic-naive vbm studies. Schizophrenia Bulletin. 2012;38(6):1297-1307. doi:10.1093/schbul/sbr134
52. Alekseichuk I, Turi Z, Amador De Lara G, Antal A, Paulus Correspondence W, Paulus W. Spatial Working Memory in Humans Depends on Theta and High Gamma Synchronization in the Prefrontal Cortex Article Spatial Working Memory in Humans Depends on Theta and High Gamma Synchronization in the Prefrontal Cortex. Current Biology.

2016;26:1513-1521. doi:10.1016/j.cub.2016.04.035

53. Uhlhaas PJ, Singer W. Abnormal neural oscillations and synchrony in schizophrenia. Nature Reviews Neuroscience. 2010;11(2):100-113. doi:10.103 $\underline{8 / \mathrm{nrn} 2774}$

54. Selvaraj S, Bloomfield PS, Cao B, Veronese M, Turkheimer F, Howes OD. Brain TSPO imaging and gray matter volume in schizophrenia patients and in people at ultra high risk of psychosis: An [11C]PBR28 study. Schizophrenia Research. 2018;195:206-214. do i:10.1016/j.schres.2017.08.063

55. Selvaraj S, Arnone D, Cappai A, Howes O. Alterations in the serotonin system in schizophrenia: A systematic review and meta-analysis of postmortem and molecular imaging studies. Neuroscience and Biobehavioral Reviews. 2014;45:233-245. doi:10.1016/i.neubiorev.2014.06.00 $\underline{5}$

56. Dean B, Copolov D, Scarr E. Understanding the pathophysiology of schizophrenia: Contributions from the Melbourne Psychiatric Brain Bank. Schizophrenia Research. 2016;177(1-3):108-114. doi:1 0.1016/j.schres.2016.04.037

57. Dean B. The cortical serotonin2A receptor and the pathology of schizophrenia: A likely accomplice. Journal of Neurochemistry. 2003;85(1):1-13. doi:10.104 6/j.1471-4159.2003.01693.x

58. McGorry PD, Purcell R, Hickie IB, Yung AR, Pantelis C, Jackson HJ. Clinical staging: a heuristic model for psychiatry and youth mental health. Medical Journal of Australia. 2007;187(S7):S40-S42. do i:10.5694/j.1326-5377.2007.tb01335.x

59. Stępnicki P, Kondej M, Kaczor AA. Current concepts and treatments of schizophrenia. Molecules. 2018;23(8). doi:10.3390/molecules23082087

60. Creese I, Burt DR, Snyder SH. Dopamine receptor binding predicts clinical and pharmacological potencies of antischizophrenic drugs. Science. 1976;192(4238):481-483. doi:10.1126/science.3854

61. Kapur S, Seeman P. Antipsychotic agents differ in how fast they come off the dopamine D2 receptors. Implications for atypical antipsychotic action. Journal of Psychiatry and Neuroscience. 2000;25(2):161-166. 
62. Farde L, Nordström AL, Wiesel FA, Pauli S, Halldin C, Sedvall G. Positron Emission Tomographic Analysis of Central D1 and D2 Dopamine Receptor Occupancy in Patients Treated with Classical Neuroleptics and Clozapine: Relation to Extrapyramidal Side Effects. Archives of General Psychiatry. 1992;49(7):538-544. do i:10.1001/archpsyc.1992.01820070032005

63. Nordström AL, Farde L, Wiesel FA, et al. Central D2-dopamine receptor occupancy in relation to antipsychotic drug effects: A double-blind PET study of schizophrenic patients. Biological Psychiatry. 1993;33(4):227-235. doi:10.1016/0006-3223(93)9028 $\underline{8-\mathrm{O}}$

64. Miyamoto S, Miyake N, Jarskog LF, Fleischhacker WW, Lieberman JA. Pharmacological treatment of schizophrenia: A critical review of the pharmacology and clinical effects of current and future therapeutic agents. Molecular Psychiatry. 2012;17(12):1206-1227. doi:10.1038/mp.2012.47

65. Kim DH, Stahl SM. Antipsychotic drug development. Current Topics in Behavioral Neurosciences. 2010;4:124-139. doi:10.1007/7854_201 $\underline{0} \underline{47}$

66. Kondej M, Stępnicki P, Kaczor AA. Multi-target approach for drug discovery against schizophrenia. International Journal of Molecular Sciences. 2018;19(10):3105. doi:10.3390/ijms19103105

67. Mocci G, Jiménez-Sánchez L, Adell A, Cortés R, Artigas F. Expression of 5-HT2A receptors in prefrontal cortex pyramidal neurons projecting to nucleus accumbens. Potential relevance for atypical antipsychotic action. Neuropharmacology. 2014;79:49-58. doi:10.1016/j.neuropharm.2013.10.02 1

68. Li P, L. Snyder G, E. Vanover K. Dopamine Targeting Drugs for the Treatment of Schizophrenia: Past, Present and Future. Current Topics in Medicinal Chemistry. 2016;16(29):3385-3403. doi:10.2174/15680 $\underline{26616666160608084834}$

69. Meltzer HY, Matsubara S, Lee JC. Classification of typical and atypical antipsychotic drugs on the basis of dopamine D-1, D-2 and serotonin2 pKi values. Journal of Pharmacology and Experimental Therapeutics. 1989;251(1).

70. Miyamoto S, Duncan GE, Marx CE, Lieberman JA. Treatments for schizophrenia: A critical review of pharmacology and mechanisms of action of antipsychotic drugs. Molecular Psychiatry. 2005;10(1):79-104. doi:10.1038/sj.mp.4001556
71. Davis RE, Correll CU. ITI-007 in the treatment of schizophrenia: from novel pharmacology to clinical outcomes. Expert Review of Neurotherapeutics. 2016;16(6):601-614. doi:10.1080/14737175.2016.1174 $\underline{577}$

72. Correll CU, Davis RE, Weingart M, et al. Efficacy and Safety of Lumateperone for Treatment of Schizophrenia: A Randomized Clinical Trial. JAMA Psychiatry. 2020;77(4):349-358. doi:10.1001/jamapsyc hiatry.2019.4379

73. Blair HA. Lumateperone: First Approval. Drugs. 2020;80(4):417-423. doi:10.1007/s40265-020-01271-6

74. FDA Label. Lumateperone Drug Prescribing and Safety Information. Accessed July 20, 2020. https://w ww.accessdata.fda.gov/drugsatfda_docs/label/2019/20 9500s000lbl.pdf

75. Vanover KE, Davis RE, Zhou Y, et al. Dopamine D2 receptor occupancy of lumateperone (ITI-007): a Positron Emission Tomography Study in patients with schizophrenia. Neuropsychopharmacology. 2019;44(3):598-605. doi:10.1038/s41386-018-0251-1

76. Kantrowitz JT. The Potential Role of Lumateperone - Something Borrowed? Something New? JAMA Psychiatry. 2020;77(4):343-344. doi:10.10 01/jamapsychiatry.2019.4265

77. Corponi F, Fabbri C, Bitter I, et al. Novel antipsychotics specificity profile: A clinically oriented review of lurasidone, brexpiprazole, cariprazine and lumateperone. European Neuropsychopharmacology. 2019;29(9):971-985. doi:10.1016/i.euroneuro.2019.0 $\underline{6.008}$

78. Snyder GL, Vanover KE, Zhu H, et al. Functional profile of a novel modulator of serotonin, dopamine, and glutamate neurotransmission.

Psychopharmacology. 2015;232(3):605-621. doi:10.100 7/s00213-014-3704-1

79. Greenwood J, Acharya RB, Marcellus V, Rey JA. Lumateperone: A Novel Antipsychotic for Schizophrenia. Annals of Pharmacotherapy. Published online June 26, 2020:106002802093659. doi:10.1177/1 060028020936597

80. Lieberman JA, Davis RE, Correll CU, et al. ITI-007 for the Treatment of Schizophrenia: A 4-Week Randomized, Double-Blind, Controlled Trial. Biological Psychiatry. 2016;79(12):952-961. doi:10.101 6/j.biopsych.2015.08.026 
81. Kane JM, Vanover KE, Durgam S, et al. P.671

Efficacy and safety of lumateperone tosylate $42 \mathrm{mg}$ in the treatment of schizophrenia: A pooled analysis of phase 2 and 3 studies. European

Neuropsychopharmacology. 2019;29:S453-S454. doi:1

0.1016/j.euroneuro.2019.09.642
82. Meyer JM. Lumateperone for schizophrenia. Current Psychiatry. 2020;19(2):33-39. 